\title{
XIX-wieczny rękopis \\ z polskich archiwów prywatnych zawierający dwa dokumenty dotyczące Karaimów trockich
}

\author{
Anna Sulimowicz \\ Uniwersytet Warszawski, Wydział Orientalistyczny \\ Zakład Turkologii i Ludów Azji Środkowej
}

\section{A nineteenth-century manuscript containing two documents referring to the Karaims of Troki}

Summary: This article presents the content of two handwritten documents. The first dates from 1813 and concerns the power of attorney granted by the Troki community to Joachim Łabanos, the son of the last voyt (shofet) of the Troki Karaim so that the latter may represent the community before the courts and the authorities. It may be regarded as an attempt to restore to a certain extent the position of the voyt who after the partition of Poland had been deprived of those prerogatives granted to him by the Grand Dukes of Lithuania and the Kings of Poland. However, three years later the power of attorney was revoked and the blank pages of this document were reused to draw up a lawsuit filed by Labanos against Judith and Joseph Firkowicz, Abraham Kobiecki and Joseph Kobiecki. Łabanos demanded compensation for expenditure he had incurred on preparations for his son Elias' aborted marriage to Abraham Kobiecki's daughter, Judith who instead of marrying the young Łabanos had run away with Joseph Firkowicz. These documents shed some light on the position of the tabanos family after it lost its leading role in the Troki Karaim community.

Keywords: Karaims in Lithuania, Troki Karaims, Karaite shofet, Łabanos, Karaim marriage 
Rozpoczęty w 2012 r. projekt „Katalog rękopisów i starodruków karaimskich”, realizowany dzięki wsparciu Narodowego Centrum Nauki ${ }^{1}$, miał na celu skatalogowanie przechowywanych w prywatnych kolekcjach w Polsce rękopisów i druków stanowiących zabytki języka karaimskiego. Przy okazji kwerendy natrafiono nie tylko na materiały interesujące pod względem językoznawczym, lecz również na różnego rodzaju dokumenty, sporządzone w innych językach niż karaimski, a dotyczące dziejów społeczności karaimskich w Polsce i na Litwie oraz na Krymie.

Jednym z takich obiektów jest pochodzący z początków XIX w. dokument dotyczący rodziny Łobanosów, z której w czasach Rzeczpospolitej wywodzili się karaimscy wójtowie. Jego treść nie była dotąd publikowana. Obiekt znajduje się w rękach prywatnych i stanowi część rodzinnego archiwum. Do Polski manuskrypt trafił po II wojnie światowej, przywieziony z Trok w ramach tzw. repatriacji.

\section{Opis obiektu}

Rękopis o numerze inw. III.101.12 składa się z dwóch dokumentów różnej treści spisanych na jednym, złożonym na pół arkuszu papieru, na powstałych w ten sposób kartach 1 recto oraz 1 verso i 2 recto. Folio 2 verso pozostaje pusta. Wymiary karty: $345 \times 205 \mathrm{~mm}$. Arkusz rosyjskiego papieru stemplowego o wartości 50 kopiejek - na folio 1 recto w prawym górnym rogu okrągła pieczęć skarbowa z godłem pośrodku i napisem w otoku: Листъ 1812 года цъна 50 копъекъ. Раpier czerpany, żeberkowy, koloru kremowego, pożółkły, krawędzie nierówne. Atrament galusowy, ciemnobrązowy. Różni kopiści. Na folio 2 recto odcisk pieczęci okrągłej w kolorze czarnym: w polu środkowym w górnej części rosyjskie godło imperialne, poniżej w owalu portret cara Pawła I, w otoku napis: Pieczęć magistratu miasta powiatowego Trok.

Stan zachowania dobry. Zabrudzenia i zaplamienia. Ślady składania dokumentu w poprzek dwukrotnie, przy linii zgięcia zaciek na krawędzi kart.

\section{Zawartość rękopisu}

Rękopis, jak było wspomniane wyżej, zawiera dwa dokumenty. Pierwszy z nich to pełnomocnictwo udzielone przez członków zarządu gminy Joachimowi Łabanosowi Wójtowiczowi, zapisane na folio 1 recto. Nosi ono datę 10 października

$1 \quad$ Numer projektu 2011/03/D/HS2/00618. 
1813 r. Następnie puste karty 1 verso i 2 recto wykorzystano do zapisania drugiego z dokumentów, pozwu skierowanego przez tegoż Joachima 11 lutego 1816 r., a tekst pełnomocnictwa kilkakrotnie przekreślono.

\section{Identyfikacja osób występujących w dokumentach}

Osobą, której imię pojawia się w obu dokumentach, jest Joachim Łabanos, urodzony około roku 1779 r., a zmarły w 1820². Jego imię religijne (שם הקודש) brzmiało Nachamo ${ }^{3}$. Ojciec Joachima, Samuel syn Abrahama (ok. 1734-1805) był ostatnim karaimskim wójtem (Mann 1972: 606-607, 619-618), stąd przydomek „Wójtowicz”. Według spisu z roku 1811 Joachim był żonaty z Szełomitą Abramowną przybyłą do Trok z powiatu upickiego w 1797 r., z która miał syna Eliasza (ok. 1798 - przed 1880). Imię religijne Eliasza brzmiało Eliazar. Wnukiem Eliasza był Józef Łobanos (1880-1947), karaimski duchowny i działacz społeczny, poeta, autor sztuk teatralnych, tłumacz „Pana Tadeusza” Adama Mickiewicza na język karaimski.

W pełnomocnictwie dla Joachima wymienionych zostało 11 „kahalnych”, czyli członków zarządu gminy:

- Chaim Dubiński (ur. ok. 1747-1821) - syn Józefa, w spisie z 1834 r. wspomniany jako syn Jeszui; w spisie z 1811 r. figuruje, podobnie jak pozostali członkowie gminnej starszyzny, w grupie mieszczan, jako głowa rodziny numer 17;

- Józef Kobiecki (ur. 1740-1818) - syn Marka; w spisie z roku 1811 rodzina numer 15; adnotacja: ,ułomny”;

- Jakub Kobiecki (ur. ok. 1759-1813) - syn Szymona; numer 18; sygnatariusz spisu rewizyjnego z 1811 r.;

2 Daty życia osób występujących w dokumencie ustalono na podstawie regestrów i spisów rewizyjnych z lat 1765, 1795, 1811, 1834 i 1858 przechowywanych w Litewskim Państwowym Archiwum Historycznym w Wilnie oraz ksiąg metrykalnych Karaimskiego Zarządu Duchownego w Trokach znajdujących się w zbiorach Biblioteki Wróblewskich Litewskiej Akademii Nauk w Wilnie. W tym miejscu pragnę serdecznie podziękować Marioli Abkowicz za udostępnienie skanów i konsultacje merytoryczne.

3 Por. rkp III.101.21 k. 1 verso, gdzie po nazwisku "Joachim Łabanos” widnieje podpis alfabetem hebr. נחמו לבנוס.

4 אליעזר: Tamże.

5 Współczesna postać nazwiska: Kobecki. 
- Józef Kapłanowski (ur. ok. 1760-1817) - syn Abrahama; w spisie z 1811 r. wymieniony wśród przybyłych z powiatu upickiego (bez daty przybycia); w spisie z 1834 rodzina $\mathrm{nr} 37$;

- Symon (Szymon) Firkowicz (ur. ok. 1755) - według spisu z 1811 r. syn Azariasza; nr 7; w spisie z 1834 r. figuruje Symon Firkowicz syn Zoracha, duchowny, lat 79 (urodzony ok. 1755), być może mimo różnych imion ojca to ta sama osoba. Nie odnotowany w revizskiej skazce z 1858 r, przy poprzednim spisie w 1850 r. odnotowano natomiast jego syna, starszego hazzana Gabriela lat 32 (ur. 1822), zięcia Abrahama Firkowicza;

- Zerubabel Samuelowicz - w spisie Karaimów mieszkańców Nowego Miasta z 1765 r. zapisany jako syn Samuela Zarachowicza „przy piersiach” (k. 3v), z czego wynika, że najprawdopodobniej urodził się w tym samym roku i na przełomie XVIII i XIX w. przeniósł do Trok; w spisie z 1811 r. figuruje pod imieniem Zachariasz lat 45 (ur. ok. 1766), z adnotacja „przybyły”; w spisie z 1834 r. jako Zachariasz syn Samuela Chorczenko, lat 67 (ur. ok. 1767);

- Ananiasz Kobiecki (ur. ok. 1783 - przed 1850) - syn wyżej wymienionego Józefa; w spisie z 1811 r. odnotowany razem z ojcem pod nr 15, a w 1834 r. samodzielnie pod nr 25. Nie figuruje w spisie z 1858 r.;

- Abram Aronowicz (ur. ok. 1778 - przed 1850) - w spisie z 1811 r. nr 4: Abraham Aarona (syna Szymona) syn; W spisie z 1834 r. (nr 9): Abraham Bezekiewicz, lat 55 (ur. 1779); w spisie z 1858 (nr 4): Abraham Bezekowicz, lat 78 (ur. 1780);

- Szołom Markowicz [Juchniewicz] (1769 - przed 1816) - w spisie z 1811 r. wymieniony jako pierwszy wśród nowoprzybyłych z powiatu upickiego. W spisie z 1834 r. figurują już tylko jego żona i syn Nechemiasz;

- Jakub Ławrzecki (ur. ok. 1755) - syn Marka; odnotowany w spisach z lat 1811 i 1834 pod nr 1.; nie odnotowany w spisie z 1858 r., prawdopodobnie zmarł przed rokiem 1850; sygnatariusz spisu rewizyjnego w 1811 r.;

- Izak Ławrzecki (ur. ok. 1759-1816) - syn Marka; w spisie z 1811 r. pod numerem nr 18: Izak syn Marka, lat 52 (ur. 1759); brat wyżej wymienionego Jakuba - obaj figurują w spisie z 1765 r. wraz z ojcem opisanym jako ,gospodarz mieszkający w karczmie Wielmożnego Pana Podkomorzego Województwa Trockiego". 
Drugi dokument będący pozwem za niedotrzymanie obietnicy małżeństwa wymienia wspomnianych już Joachima Łabanosa oraz jego syna Eliasza jako powodów oraz stronę pozwaną w osobach: Józefa, Abrahama i Judyty Kobieckich oraz Józefa Firkowicza. Jako uczestnicy zdarzenia wymienieni są syn Abrahama, Symon oraz szwagier Ananiasz, którego nazwiska nie podano.

W spisie rewizyjnym z 1811 r. pod numerem 19 znajdujemy Abrahama Kobieckiego syna Symona lat 52, żonatego z Anną córką Józefa. Wynika z tego, że pozwany Józef był dziadkiem Judyty nie po mieczu (jak można by się spodziewać po fakcie, że oboje noszą to samo nazwisko), lecz po kądzieli. Abraham i Anna mieli dwóch synów: Symona (ur. ok. 1790) i Salomona (ur. ok. 1800), oraz dwie córki: Sarę (ur. ok. 1794) oraz Judytę (ur. ok. 1803). Warto w tym miejscu wspomnieć, że kolejne dziecko tej pary, urodzony w 1814 r. Azariasz, odnotowany w spisie z 1834 r., to ojciec Szymona Kobeckiego, poety ${ }^{6}$.

Identyfikacja Józefa Kobieckiego mogłaby nastręczać pewnych trudności, ponieważ nie znamy imienia jego ojca, a córka Anna nie figuruje przy ojcu w poprzednich spisach (w $1765 \mathrm{r}$. prawdopodobnie jeszcze się nie urodziła, w tym z 1795 jest już zamężna). Jednakże w spisie z 1811 znajdujemy tylko jednego Józefa o tym nazwisku i w wieku odpowiednim, by być dziadkiem Judyty. Jest to wpisany pod numerem 15 Józef Kobiecki, syn Marka, członek zarządu gminy i sygnatariusz pełnomocnictwa spisanego na folio $1 \mathrm{r}$. Identyfikację potwierdza fakt, że Józef ma syna Ananiasza (ur. ok. 1783), wymienionego w dokumencie szwagra (brata żony) Abrahama.

Józefa Firkowicza można natomiast zidentyfikować już jako męża Judyty w spisie z 1834 r. - jest synem Sałomona i ma lat 48 (ur. ok. 1786). W spisie z 1811 figuruje jako 26-letni pod numerem 21 z ojcem Sałomem synem Zaracha (bez podanego nazwiska), zmarłym, jak odnotowano, w $1806 \mathrm{r}$.

\section{Okoliczności sporządzenia dokumentów}

Pełnomocnictwo udzielone 10 października 1813 r. Joachimowi Łabanosowi ma charakter pełnomocnictwa procesowego ogólnego, uprawniającego do reprezentowania gminy wobec sądów wszelkich instancji w Księstwie Litewskim. Nic nie wskazuje, by wydano je w związku z konkretnym procesem. Wydaje się natomiast dość prawdopodobne, że upoważnienie mogło stanowić próbę

6 Por. M. Abkowicz, A. Sulimowicz, Nowe dane o biografii karaimskiego poety Szymona Kobeckiego w tym tomie „Almanachu Karaimskiego”. 
legitymizacji pozycji Joachima jako wójta, pozbawionego w porozbiorowej rzeczywistości uprawnień sądowniczych, ale wciąż zdolnego do występowania w imieniu gminy. Funkcja karaimskiego wójta, regulowana przywilejami królów polskich i wielkich książąt litewskich, nie została uznana przez zaborcze władze rosyjskie, jednakże ojciec Joachima, Samuel syn Abrahama był także po roku 1793 określany w dokumentach jako šofeț ('wójt'). Mann wysuwa przypuszczenie, że być może Samuelowi zezwolono dożywotnio pozostać na stanowisku wójta (Mann 1972: 618), pozbawiając go jednak większości gwarantowanych przywilejami uprawnień. Niewykluczone, że gmina lub sam Joachim próbowali w ten sposób zapewnić kontynuację tradycji.

Nie wiadomo, czy i przy jakich okazjach pełnomocnictwo było wykorzystywane. Stanowisko wójta, od 1742 r. tytułowanego „wójtem generalnym Synagogi karaimskiej”, było przez niemal cały wiek XVIII zajmowane przez przedstawicieli kolejnych pokoleń Łabanosów, co powodowało narastanie opozycji wobec uprzywilejowanej pozycji tej jednej rodziny (Gąsiorowski 2008: 291). Być może więc to jacyś oponenci „wójtowiczów” sprawili, że gmina wycofała uprawnienia nadane Joachimowi tym dokumentem. Tak czy inaczej pełnomocnictwo utraciło ważność i zaledwie trzy lata później niezapisane jego karty wykorzystano do sporządzenia pozwu. Joachim Łabanos domaga się w nim odszkodowania za wydatki poczynione na poczet przyszłych zaślubin swego syna Eliasza z córką Abrahama, Judytą, który to ślub nie doszedł do skutku, gdyż narzeczona uciekła z Józefem Firkowiczem. Powód wycenia swe „ekspensa” na kwotę co najmniej 100 złotych, na co składał się przede wszystkim koszt posłania syna na nauki do Łucka „dla większej ambicyi, że [...] ma ślubne związki spełnić”. Najwyraźniej ojciec uznał, że fakt studiów w Łucku podniesie prestiż 18-letniego narzeczonego. Wskazuje to też pośrednio na znaczenie Łucka jako ośrodka karaimskiej nauki. W tym czasie działał tam jeszcze Mordechaj Sułtański (ok. 1772-1863), który dopiero w początkach lat 20. XIX w. przeniósł się na stałe na Krym. Łabanosowie ponieśli też wydatki na zaproszenie gości i prezenty, które miano wyszczególnić w kontrakcie ślubnym (kar. šetar, šatar). Z treści dokumentu nie wynika jednoznacznie, czy zaręczyny faktycznie się odbyły. Na poczet swoich roszczeń Joachim wystąpił o zajęcie posagu Judyty pozostającego w ręku jej ojca. Wydaje się przy tym, że szczególnie dotkliwe, może nawet bardziej od materialnych szkód, były docinki, których nie szczędzili ojcu i synowi zwycięski rywal i jego wybranka. One także skłoniły Łabanosów do wstąpienia na drogę sądową i domagania się zaprzestania szykan pod groźbą odpowiedzialności osobistej i materialnej. Niedotrzymanie przyrzeczenia małżeństwa musiało być ogromnym skandalem, 
który niewątpliwie naruszał honor i godność rodziny Łabanosów chlubiącej się dawnym i zaszczytnym rodowodem ${ }^{7}$.

Nie wiemy i zapewne nigdy się nie dowiemy, jakie były powody decyzji Judyty, która według spisu z 1811 r. mogła w tym czasie liczyć zaledwie około 13 lat. Zgodnie z trzecim Statutem Litewskim ${ }^{8}$ dziewczyna mogła zawrzeć małżeństwo po osiągnięciu trzynastego roku życia (Sarcevičienė 2011: 255) i jeszcze w początkach wieku XIX w. był to wiek, który powszechnie, niezależnie od wyznania, uważano za wystarczający do zawarcia małżeństwa, choć nie równoznaczny z pełnoletnością (Liedke 2013: 23). Tendencja do zawierania małżeństw w bardzo młodym wieku (przez obie płcie, przy czym dziewczęta wychodziły za mąż w wieku jeszcze młodszym niż chłopcy) była najbardziej widoczna w społeczności żydowskiej, gdzie dziewczynki uznawano za zdolne do małżeństwa już od ukończenia dwunastego roku życia, chłopców zaś od trzynastego (Umińska 1995: 153). Przyczyną takiego stanu rzeczy było z jednej strony pragnienie zapobiegania przedmałżeńskim kontaktom seksualnym, z drugiej zaś strony niska średnia długość życia - wczesne małżeństwo dawało młodym większe szanse na wsparcie materialne ze strony rodziców, rodzicom zaś zapewniało wpływ na przyszłość dzieci (Goldberg 1997: 5). Nie dysponujemy dokładnymi statystykami dotyczącymi wieku zawierania małżeństw przez Karaimki w tym okresie, spisy rewizyjne pozwalają jednak stwierdzić, że tak wcześnie zawierane małżeństwa nie były czymś wyjątkowym, choć na ogół wiek panien młodych był wyższy ${ }^{9}$. Starsza siostra Judyty, Sara, urodzona w 1794 r., w momencie wydarzeń opisanych w dokumencie była już od ośmiu lat zamężna za Kapłanowskim z powiatu upickiego, co oznacza, że wyszła za mąż w wieku lat 14. Także ich matka, Anna córka Józefa, najstarszego syna urodziła jako piętnastolatka, musiała więc również bardzo młodo zostać mężatką. Być może jednak Judyta była nieco starsza - późniejsze spisy, a także księgi metrykalne wskazują na rok 1800 jako jej rok urodzenia. Oznaczałoby to, że w chwili ucieczki miała lat 16.

7 Członkowie rodziny Łobanosów w XVII i XVIII w. pełnili funkcję karaimskich wójtów. Mann wymienia czterech szofetów noszących to nazwisko (Mann 1972: 612-619), są jednak przesłanki, by twierdzić, że wymieniony w dokumencie z $1622 \mathrm{r}$. Abraham b. Shalom również należał do tej rodziny.

8 Ogłoszony w 1588 r., obowiązywał do roku 1840.

9 W drugiej połowie XIX w., z którego to okresu dostępne są księgi metrykalne, Karaimki wychodziły za mąż najczęściej w wieku 20-25 lat, choć panny młode pomiędzy 16 a 20 rokiem życia też nie należały do rzadkości. Por. Księgi metrykalne gminy karaimskiej w Trokach (Abkowicz, M., informacja ustna, listopad 2016). 
Z dokumentu wynika, że Judyta uciekła dobrowolnie, a ucieczkę zaplanowali oboje z Józefem (dużo od niej starszym, bo 29-letnim!) w tajemnicy przed jej ojcem. Pomocnikami w realizacji planu byli za to jej brat Symon i wuj Ananiasz. Nasuwa to przypuszczenie, że być może rodzice zaaranżowali korzystne pod względem materialnym i prestiżowym małżeństwo Judyty z młodym Łobanosem, a młodsi członkowie rodziny sprzyjali raczej swemu rówieśnikowi (Symon miał wówczas lat 26, Ananiasz - 32) i zapewne koledze. W spisie z 1811 r. przy Symonie (określanym tu jako „rezolutny na wszystko”) poczyniono uwagę: „wyszedł do uniwersitetu wileń[skiego] pod № 98 w medycynie przez Dziekana tegoż oddziału zaświadczenie iako uczniowi iest wydane" (k 45v). Na tej podstawie można byłoby dalej spekulować, czy podczas studiów w Wilnie młody Kobiecki zetknął się z kiełkującymi ideami romantyzmu i czy to właśnie skłoniło go do udzielenia pomocy siostrze w uniknięciu aranżowanego małżeństwa i połączeniu się z tym, kogo - jak możemy przypuszczać - obdarzała uczuciem.

Kwestią otwartą pozostają też motywy Józefa Firkowicza - według dzisiejszych standardów związek niemal trzydziestoletniego mężczyzny z szesnastolatką budziłby kontrowersje, wówczas jednak było to społecznie akceptowane. Mężczyźni wstępowali zazwyczaj w związek małżeński w bardziej zaawansowanym wieku niż kobiety, co związane było z koniecznością osiągnięcia odpowiedniego statusu materialnego umożliwiającego założenie rodziny (Chwalba: 133). Wydaje się, że Józefem kierowało raczej uczucie niż względy majątkowe, choć z osób biorących udział w zdarzeniu zajmuje on najniższą pozycję w spisie, w którym kolejność odzwierciedla status społeczny i materialny rodziny. Judyta była więc dla niego dobrą partią. Jednakże zgodnie z postanowieniami Statutów Litewskich dziewczyna mogła zawrzeć małżeństwo jedynie za zgodą rodziców lub opiekunów ${ }^{10}$, w przeciwnym razie traciła prawo do posagu (Sarcevičienè 2011: 250-251), który w tym wypadku, jak wynika z dokumentu, pozostał w ręku jej ojca i którego zajęcia w poczet odszkodowania domagał się w pozwie Łabanos. Na postępek Firkowicza mogło wpłynąć jeszcze coś innego: jego matka zmarła w roku 1797, dziadek w 1799, babka w 1803, ojciec w 1806, a dwie starsze siostry były od dawna zamężne. Został więc sam i zapewne był mocno zdeterminowany, by założyć rodzinę.

Ucieczka Judyty i jej ślub „za miastem y na polu czyli też dalej”, pod którym należy, jak się wydaje, rozumieć skonsumowanie związku, postawiły rodzinę

10 Statuty przewidywały także surowe kary za porwanie dziewczyny i zmuszenie jej do małżeństwa, chyba że dobrowolnie zgodziła się na ślub, a z takim wypadkiem właśnie mamy tu do czynienia. 
Kobieckich przed faktem dokonanym. Łabanosowie nie zamierzali jednak puścić tego płazem. Trudno powiedzieć, czy „uprzykrzenia” wobec nich ze strony zuchwałej pary rzeczywiście miały miejsce, czy też sam widok małżonków był dla Joachima i jego syna trudny do zniesienia. Być może już wcześniej pomiędzy Łabanosami a Firkowiczem doszło do jakiegoś konfliktu i ten ostatni wykorzystał okazję, by mocniej dopiec adwersarzom. Na te pytania nie znamy odpowiedzi. Nie wiemy też, czy sprawa miała dalszy ciąg i czym się zakończyła, czy Kobieccy i Firkowicze zapłacili żądaną sumę, czy też zawarto ugodę. Być może w przyszłości zostaną jeszcze odnalezione inne dokumenty, które pozwolą rzucić więcej światła na tę historię.

Judyta i Józef przeżyli razem ponad pół wieku i dochowali się co najmniej sześciorga potomstwa: czterech synów (Sałamona ur. ok. 1820, Dawida ur. ok. 1824, Joela/Juliana ur. ok. 1826 i Ananija ur. ok. 1837) oraz dwóch córek (Szołomity ur. ok. 1817 i Estery ur. ok. 1831). Józef zakończył życie 21 sierpnia 1869 r. Niespełna dwa lata później, 7 lipca 1871 r. zmarła na cholerę Judyta.

Eliasz Łobanos w końcu również założył rodzinę. Ożenił się z Basią (Bat Szewą) córką Józefa i miał z nią dwóch synów: młodo zmarłego Nachamo (ur. ok. 1825) i Josefa (ur. ok. 1831-1904), późniejszego skarbnika trockiej gminy. Skandal, którego Eliasz był uczestnikiem, z czasem zatarł się w pamięci karaimskiej społeczności i pozostał szerzej nieznany aż do chwili, gdy w marcu br., po 200 latach od tamtych wydarzeń został odnaleziony rękopis nr III.101.12.

\section{Materiały archiwalne}

\section{Skróty}

BWLAN = Biblioteka im. Wróblewskich Litewskiej Akademii Nauk w Wilnie

LPAHW = Litewskie Państwowe Archiwum Historyczne w Wilnie

RBNStP = Rosyjska Biblioteka Narodowa w Sankt Petersburgu

Regestr Karaimów trockich przez J.M. pana Tadeusza Kuszelewskiego, rewizora od wielmożnych panów Józefa de Raesa, wojskiego i podwojewodziego, Dominika Tańskiego, podstarościego, urzędników województwa trockiego oraz Abrahama Łabanosa, wójta synagogi Karaimów litewskich, Ezreasza Symonowicza, Zoracha Raeckiego starszych kahalnych zastanych, sporządzony et die 16 Januarii anno 1765 przed nami komisarzami w mieście Trokach zaprzysiężony. LPAHW SA-3732 k. $2 \mathrm{r}-4 \mathrm{v}$.

Regestr karaimów w Nowym Mieście iako też y po partykularzach do Szkoły Nowomiejskiej przysłuchujących y przykładaiących się w roku 1765 przez nas rewizorów sporządzonych w kahale Nowomiejskim. RBNStP F946-240. K. 1r-5v. 
Rewizska skazka. Roku 1811 miesiąca Septembra 26 die Guberni Litewsko Wilenskiey Pttu [powiatu] Tr[ockie]go Kahału Karaimskiego w mieście Trokach będącego o nayduiących się męskiej y żenskiej płci Karaimach. LPAHW F515 op. 15. T. 204. K. 41-48.

Rękopis nr inw. III.101.21. 1818. Umowa pożyczki pod zastaw. Kolekcja prywatna.

Revizskaâ Skazka. Tysâča Vosimsot" Tridcat" Četvertago Goda Aprelâ Dvadcat' Vos'mogo Dnâ Vilenskoj Gubernìi Uezdnago Goroda Trok" o sostoâščih" mužska i ženska Pola Karaimah". LPAHW F515 op. 15. T. 590. K. 282-300, 305-307, 318.

Revizskaâ Skazka. Tysâča vosem'sot" pât'děsât' vos'mogo goda aprěl'â pervogo dnâ Vilenskoj Gubernìi uezdnogo Goroda Trok" o sostoâščih" mužeskago i ženskago pola dušach obŝestva měščan Karaimov". LPAHW F515 op. 25. T. 112. K. 527-554.

Księgi metrykalne gminy karaimskiej w Trokach. BWLAN F301-288. 177 kk.

\section{Bibliografia}

Chwalba, Andrzej (red.). 2004. Obyczaje w Polsce od średniowiecza do czasów wspólczesnych. Warszawa.

Gąsiorowski, Stefan. 2008. Karaimi w Koronie i na Litwie w XV-XVIII wieku. Kraków - Budapeszt.

Gloger, Zygmunt. 1900. Encyklopedia staropolska. T. 3. Warszawa.

Goldberg, Jacob. 1997. Jewish Marriage in Eighteenth-Century Poland. [W:] Hundert, Gershom David (red.). Jews in Early Modern Poland. (= Studies in Polish Jewry 10). London - Portland: 3-39.

Liedke, Marzena. 2013. Uwagi o wieku uprawniajacym do zawarcia małżeństwa $w$ Wielkim Księstwie Litewskim w XVI-XVIII wieku. „Przeszłość Demograficzna Polski” 32: 7-24.

Mann, Jacob. 1972. Texts and Studies in Jewish History and Literature. Vol. II. Karaitica. New York.

M. Arcta słownik staropolski. 1914. Opracowali Krasnowolski, A. (t. 1), W. Niedźwiedzki (t. 2). Warszawa.

Sarcevičienè, Jolite. 2011. Kobieta. [W:]: Kultura Wielkiego Księstwa Litewskiego. Analizy i obrazy. Kraków: 249-267.

Umińska, Bożena. 1995. Pozycja kobiety $w$ tradycyjnym prawie żydowskim. [W:] Borzymińska, Z., Żbikowski, A., Żebrowski, R. (red.). Studia z dziejów Żydów w Polsce. Materiały edukacyjne dla szkół średnich i wyższych. T. 1. Warszawa: 149-167. 


\section{Tekst}

[1r]

My kahalni zboru karaimskiego nowotrockiego, niżej na podpisaniu rąk naszych wyrazem wiadomo czyniemy tym naszym generalnym pełnomocnym plenipotencyjnym pismem dokumentem star[o]zakon[nemu] Joachimowi Łabanosowi, wójtowiczowi i obywatelowi tegoż miasta wydanym i służącym na to, iż my Karaimi, mając różne interesa, gdy onych sami osobami własnemi popierać, ani też dopilnować z racji potrzeb i okolicznościów domowych nie możemy, a za tym wyż wspomnionego Joachima Łabanosa, wójtowicza zboru naszego za generalnego i pełnomocnego plenipotenta do wszystkich, a wszelkich interesów i zdarzeń wypadających w Księstwie naszym Litewskim - za generalnego i pełnomocnego plenipotenta obrawszy, onemu nasze ogólne interesa całkiem przyporuczamy do poparcia onych w każdym sądownictwie mocnym stanowiemy, tudzież do podawania próśb, instalowania plenipotentów i co tylko w sprawach interesach i potrzebach naszego kahału wypadać będzie, i potrzebnym być się okaże, i rzeczy uskuteczniać, załatwiać i czynić koniecznym natrafi się we wszelkich jurysdykcjach moc nadajemy, a cokolwiek uczynić postanowi, i jak obejdzie się za ważno i niewzruszono mieć przyrzekamy jakoż i obowiązujemy się - ku twierdzy zaś większej takowy generalny y pełnomocny plenipotencyjny dokument przy świadectwie ustnie i oczywisto od nas pieczętarzów ${ }^{11}$ podpisami rąk naszych stwierdzamy. Dat[um] roku 1813. miesiąca Oktobra 10 dnia.

\begin{tabular}{|c|c|}
\hline Chaim Dubiński & 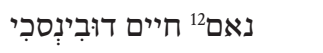 \\
\hline נאם יוסף קוביצכי & Józef Kobiecki \\
\hline נאם יעקוב אורג'13 קוביצכי & Jakub Kobiecki \\
\hline נאם יוסף כפלאנווסכי & Jozef Kapłanowski \\
\hline נאם שמחה פירקווץ & Symon Firkowicz \\
\hline נאם זרבבל בן כ"מי14 שמואל זצ' & Zerubabel Samuelowicz \\
\hline נאם חנניה קובצכי & Ananiasz Kobiecki \\
\hline נאם אברהם ארוֹנו!ויץ & Abram Aronowicz \\
\hline
\end{tabular}

$11 \quad$ Pieczętarz - 1) kanclerz; 2) świadek, zaproszony do podpisania dokumentu, zob. M. Arcta słownik staropolski II 1914: 313.

12 נאם - hebr. 'poświadcza'.

13 אורג - hebr. 'tkacz'.

14 Skrót hebr. מעלת כבוד =) - כ"מ) - 'jegomość pan'.

15 Jedyny podpis zawierający tytulaturę i imię ojca podpisującego: Zerubabel syn jegomość pana Szemoela pamięć sprawiedliwego niech będzie błogosławiona. Skrót po imieniu ojca oznacza, że w tym czasie już nie żył. 


\section{Szołom Markowicz

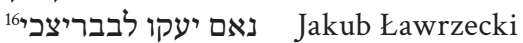 \\ Izak Eawrzecki}

Ustnie i oczewisto proszony za pieczętarza od wyż wyrażonych osób kahalnych zboru Karaimów trockich do tej plenipotencji star[o]zakon[ne$\mathrm{mu}$ ] Joachimowi Łabanosowi, wójtowiczowi i obywatelowi tegoż miasta na rzecz obszerniej we śrzedzinie ${ }^{17}$ wyrażoną wydanej, prawnie podpisuję się Hermenegild de Campio Scypion, chor[ąży] wojsk litewskich.
Ustnie i oczewisto za pieczętarza od wyż wyrażonych osób kahalnych zboru Karaimów trockich do tej plenipotencji star[o]zakonnemu Joachimowi Łabanosowi, wójtowiczowi i obywatelowi tegoż miasta na rzecz obszerniej we strzedzinie opisanej wydanej, prawnie podpisuję się - Mikołaj Billewicz Smotrytel Byłej Poczty trockiej

[1v]

Wedle ukazu Jego Imperatorskiej Mości samowładnącego całą Rosją - et caetera...,

Starozakonnym Józefowi dziadowi, Abramowi ojcowi Kobieckim do przyjęcia aresztu na wniosek Judyty Firkowiczowej w ręku Abrama jako ojca najdujący się Józefowi y Judycie Firkowiczom jako motorom sprawy = Pozew wespół $\mathrm{z}$ aresztem przed sąd magistratu trockiego ciągle sądzący się z powództwa starozakonnych Joachima, ojca Eliasza syna Łabanosów Karaimów trockich wyniesiony o to, iż co obżałowany ${ }^{18}$ Abram Kobiecki na[?] niwszy ${ }^{19}$ żałującym $^{20}$ swą córkę Judytę teraźniejszą Firkowiczową do zamążpójścia za żałującego Eliasza Łabanosa i z żałującym Joachimem jako by [jemu $]^{21}$ zrobił upewnienie na ten przedmiot Eliasza do Łucka wyprawiono na naukę dla większej ambicji, że z obżałowaną Judytą Kobiecką ma ślubne związki spełnić - co kosztowało żałujących Łabanosów rubli srebrem 90.

16 Nietypowa pisownia nazwiska z podwojonym bet zamiast podwójnego waw, jak w wersie poniżej.

17 Śrzedzina, śrzedzizna - średnica; punkt środkowy, centrum (M. Arcta słownik staropolski II 1914: 618). Tu: 'w treści dokumentu'.

18 Obżałowany - pozwany.

19 Lekcja niepewna. Może od 'namienić' - nadmienić, wspomnieć, wzmiankować?

20 Żałujący - skarżący, powód.

21 Lekcja niepewna. 
Za powrotem Eliasza z Łucka, gdy już zbliżało się do końca [mariasz] ${ }^{22}$ i zaręczynami upewniony, same oznajmienie familii na Z[?] $\mathrm{ych}^{23}$ i na ten akt zaproszenie, toż prezenta na regestrze okazać się mające kosztowały do rubli srebrnych kilkadziesiąt, i tak będąc żałujący Joachim Łabanos zapewniony wszelkie przygotowania gdy uczynil, niespodziewając się chytrego podstępku obżałowanych Józefa i Judyty Firkowiczów zdradzony i na stratę znaczną z okazji obżałowanych narażony, gdyż obżałowany Józef Firkowicz z obżałowaną Judytą w nocy [po] kryjomu namówiwszy syna obżałowanego Abrama, Symona rezolutnego na wszystko jako brata obżałowanej Firkowiczowej, toż Ananiasza szwagra biegłych i absolutnych, którzy bez wiedzy obżałowanego Abrama ojca za miastem i na polu, czyli też dalej ślub z obżałowanym Firkowiczem uprzednio nie bez podejrzenia widać znajomość mającego z obżałowaną Judytą wziąć dopuścili, przez co na znaczne ekspensa żałujących Łabanosów naraziwszy, w niczym nie nadgrodzili i jeszcze różne postępy obżałowany Firkowicz nie przestaje przeciwko żałującym czynić. Gdy dziś doświadczone szykany zmuszają żałujących Łabanosów do procederu. Przeto idą przed sąd z prośbą z obżałowanym Józefem dziadem i Abramem ojcem Kobieckimi do approbaty aresztu na osoby i ruchomość obżałowanych Firkowiczów, a szczególnie na posag Judyty w ręku ojca obżałowanego Abrama znajdujący się do finalnej rozprawy o zasądzenie strat na Regestrze pokazać się mające, a w przypadku niewystarczenia majątku obżałowanych Firkowiczów uznania sekwestracji samych osób Firkowiczów. Toż zastrzeżenia przez dekret, aby nadal żadnych uprzykrzeń, szykanów i zwad Firkowiczowie przeciwko żałującym nie ważyli się czynić pod odpowiedzią z majątku i osób o zwrot ekspens prawnych ad minimum ${ }^{24}$ złp 1000, i o to wszystko, co przez proceder wykaże się salva melioratione $e^{25}$.

Roku 1816 miesiąca Februarii 11 dnia woźny świadczę, iż takowego pozwu kopiej trzy z autentykiem zgodne w sprawie starozakonnego Joachima ojca, Eliasza syna Łabanosów Karaimów trockich, pierwszą starozakonnym Józefowi Kobieckiemu, drugą Abramowi Kobieckiemu z aresztem, trzecią Józefowi i Judycie Firkowiczom wszystkim oczewisto w ręce w mieście Trokach przed sąd magistratu trockiego popodawałem.

toż

22 Lekcja niepewna.

23 Lekcja niepewna.

24 Ad minimum - łac. 'co najmniej'.

25 Salva melioratione - łac. 'z zastrzeżeniem poprawienia' (tzn. przedmiot procesu może ulec rozszerzeniu). 
$[2 \mathrm{r}]$

Osoby i majątek [dopisano: Firkowiczów] u Józefa Kobieckiego, a posag u Abrama Kobieckiego ojca Firkowiczowej do finalnej rozprawy przyaresztowałem.

Leon Kalinowski woźny sądowy powiatu trockiego

Roku tysiąc osiemset szesnastego

miesiąca marca pierwszego dnia

Przed aktami magistratu trockiego stawając obecnie woźny wyżej wyrażony kwit swój relacyjny ${ }^{26}$ podanego pozwu urzędownie zeznał. Suscepty ${ }^{27}$ Hillary Strzemeski magistratu trockiego

Po[?] $\mathrm{y}^{28}$ pieczętne kop. 52 wzięto u tej suscepty ${ }^{29}$ Jego Imperatorskiej Mości sądu magistratu trockiego

[odcisk pieczęci]

Takowa

Pieczęć

Zgodno z Aktami świadczę
Hillary Strzemeski
Magistratu Tr[ockie]go Pisarz

[Poniżej adnotacja w języku hebrajskim w układzie prostopadłym do tekstu polskiego, zatarta, czytelny jedynie pierwszy wyraz אוֹדוֹת (hebr. 'dotyczy, odnośnie’), dalszy ciąg nieczytelny.]

26 Relacje - wszelkiego rodzaju zeznania, protesty i manifesty wpisywane do ksiąg wieczystych. Por. Ksiegi wieczyste, Gloger 1900: 109-110.

27 Susceptant - osoba przyjmująca zeznania w zastępstwie rejenta (Gloger 1900: 110).

28 Lekcja niepewna.

29 Suscepta - zeznania wpisywane do ksiąg wieczystych przechowywanych w kancelariach ziemskich lub grodzkich. Rejestrowano w ten sposób zapisy i kwity pieniężne, umowy sprzedaży, ugody, oblaty rewersów i ubezpieczenia posagowe, skargi i zażalenia (Gloger 1900: 109). 


\section{Facsimile}

\section{K. I recto}

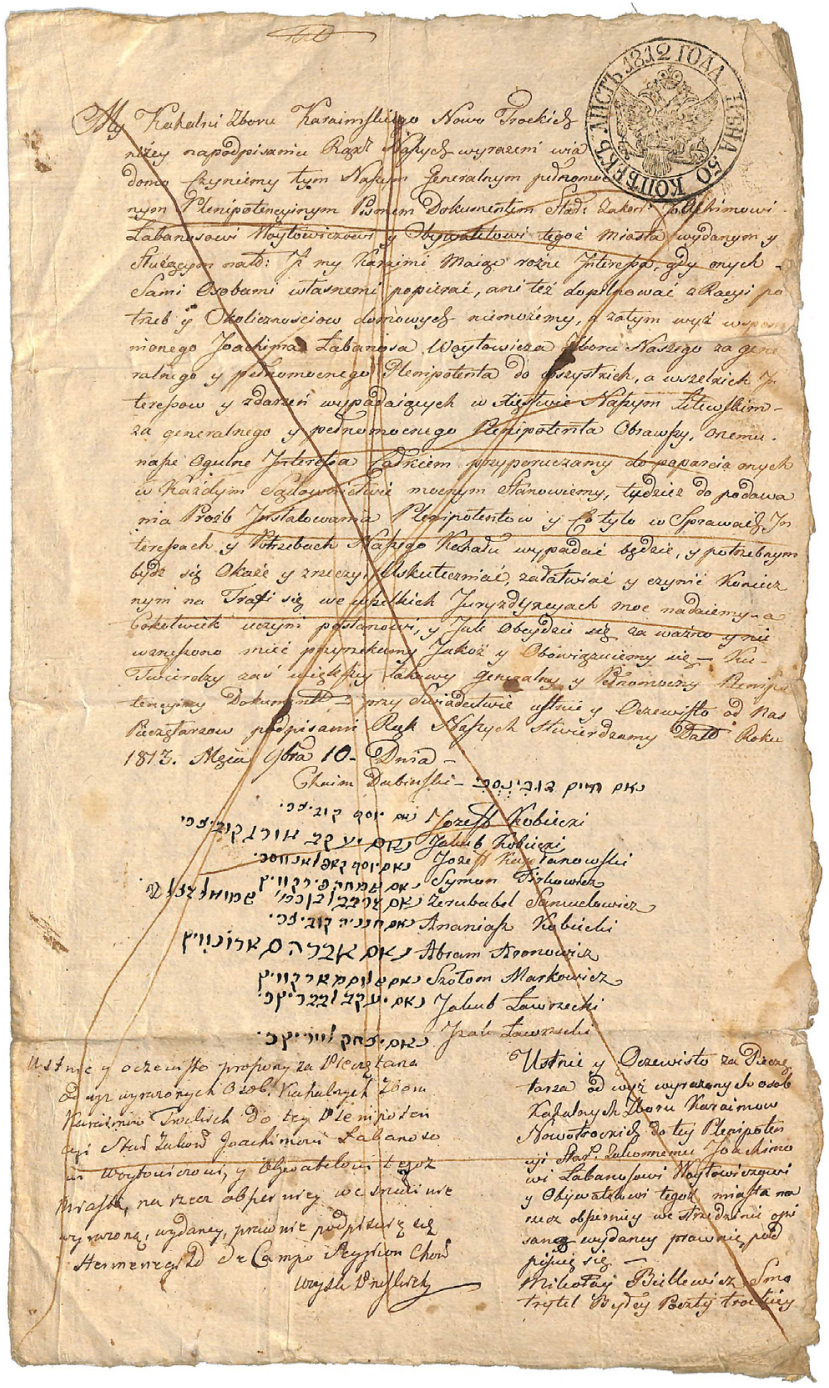




\section{K. I verso}

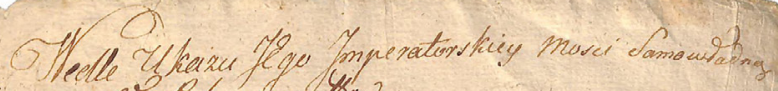

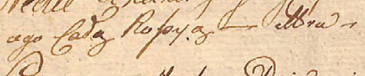

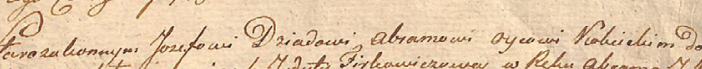

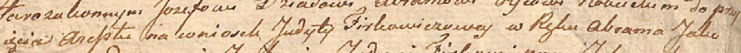

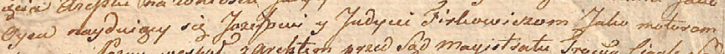

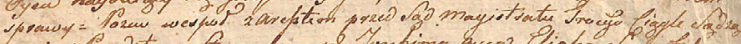

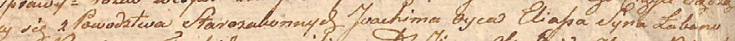

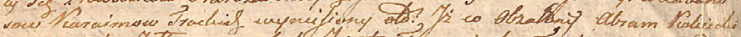

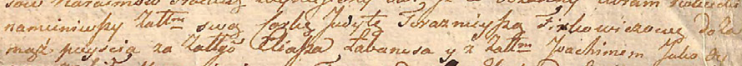

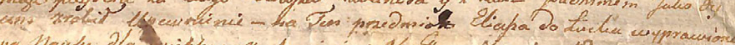

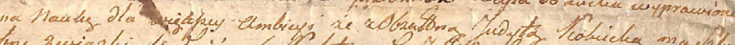

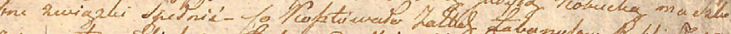

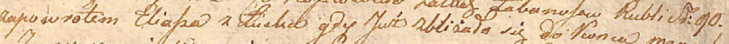

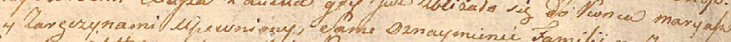

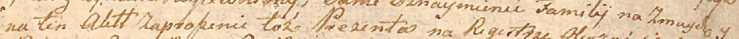

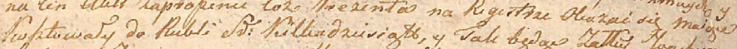

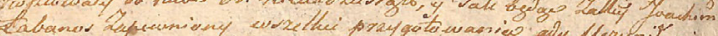

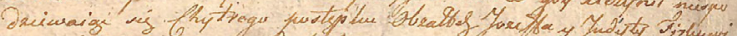

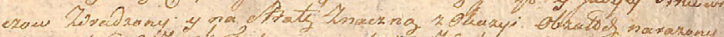

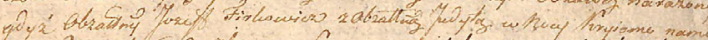
Quni

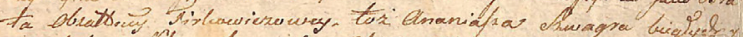

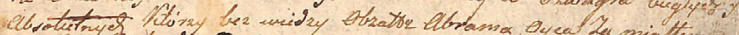

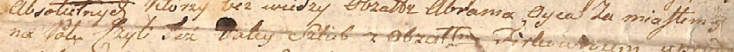

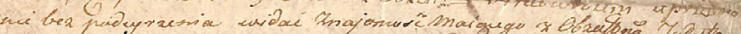

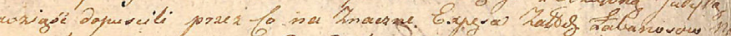

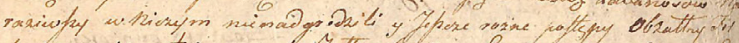

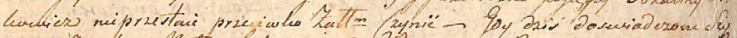

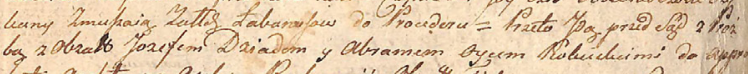

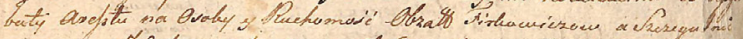

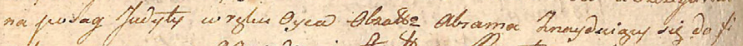

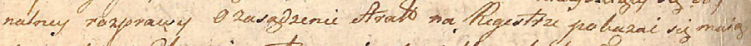

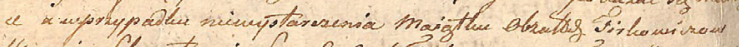

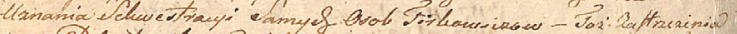

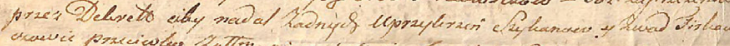

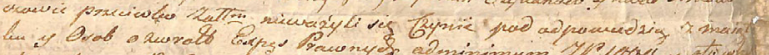

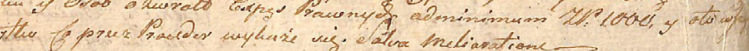

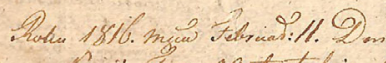

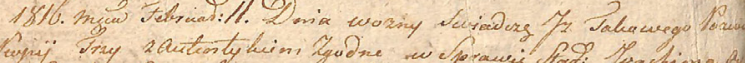
-

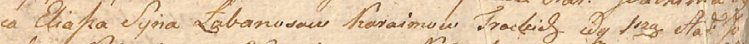

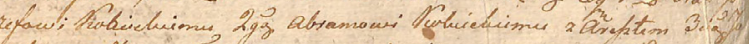

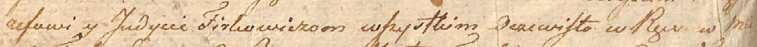

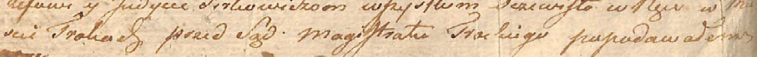
tos 


\section{K. 2 recto}

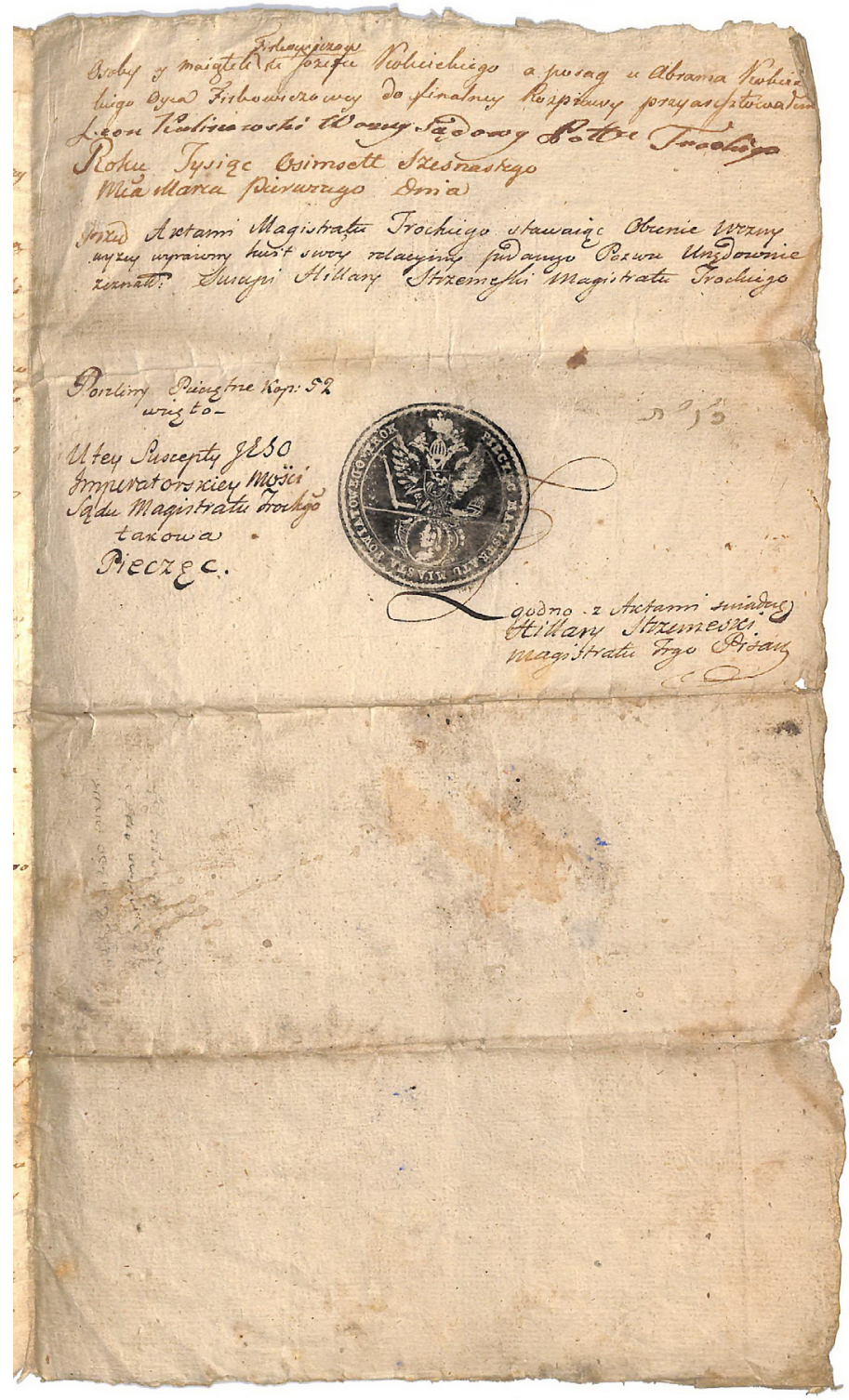


